\author{
Lecturer Adis PUŠKA (Corresponding author) PhD \\ E-mail: adispuska@yahoo.com \\ Full Professor Safet KOZAREVIĆ, PhD \\ Faculty of Economics, Univesity of Tuzla, Bosnia and Herzegovina \\ E-mail: safet.kozarevic@untz.ba \\ Assistant Željko STEVIĆ, PhD \\ Faculty of Traffic Engineering, University of East Sarajevo \\ Bosnia and Herzegovina \\ E-mail: zeljkostevic88@yahoo.com \\ Jasmin STOVRAG \\ E-mail: jstovrag@gmail.com
}

\title{
A NEW WAY OF APPLYING INTERVAL FUZZY LOGIC IN GROUP DECISION MAKING FOR SUPPLIER SELECTION
}

\begin{abstract}
Today, there is strong competition in the market, and therefore an adequate process of selecting suppliers, as one of the key activities in the supply chain management, can contribute to the company's overall business. In an empirical research that dealt with the selection of suppliers for a paper manufacturing company, it was necessary to select a supplier that would contribute to improving the environmental awareness of this company. The selection of suppliers in this paper is based on the application of the interval fuzzy logic and the group decision making model. Interval fuzzy logic was applied to the AHP and TOPSIS methods. The AHP method has determined the weights of the criteria, while TOPSIS method ranks the supplier based on the distance from an ideally positive and negative solution. Linguistic values were used to meet the criteria of supplier. Based on a practical example conducted on real suppliers, it has been established that supplier $A_{6}$ shows the best results in relation to other suppliers. These results were confirmed by sensitivity analysis.
\end{abstract}

Keywords: supplier selection, interval fuzzy logic, AHP, TOPSIS, sensitivity analysis.

\section{JEL Classification: C02, C44, L67}

\section{Introduction}

The selection of suppliers is one of the most important elements in supply chain management and logistics in a single company. In order to start production, it is necessary to procure materials, raw materials and machines. Based on this, the choice of suppliers is one of the most important aspects of planning production and its control with the company (Tamošaitiene et al, 2017). Choosing the wrong supplier violates the financial position of the company (Önüt et al, 2009), and the competitiveness of the company is undermined. In order to make this section, it is necessary to include different suppliers in the decision making, which are 
Adis Puška, Safet Kozarević, Željko Stević, Jasmin Stovrag

evaluated based on a number of criteria using different methods. This process is a fundamental problem in multi-criteria decision making (MCDM). There are many ways in which this deciding problem can be solved, and various methods such as linear programming models, stochastic methods, statistical and other methods can be used.

In addition to qualitative and quantitative criteria, it is possible to evaluate individual suppliers according to certain criteria through linguistic values. The application of linguistic values instead of traditional quantitative expressions is a useful concept for solving situations that are too complex or insufficiently determined (Yazdani et al, 2011). Linguistic values are represented in the form of a scale that needs to be transformed into numerical values in order to perform the process of selecting a supplier. In order to transform linguistic values into numerical, it is possible to use fuzzy logic. According to Zadeh (1965), fuzzy logic can be used as a narrow approach in which the fuzzy logic is an extension of classical logic and a wider approach where fuzzy logic is used in sets that do not have clear boundaries. Fuzzy approach is closer to human thinking because in the real world there are situations that are not defined and it is difficult to determine the boundaries of the set. This is particularly present when it comes to qualitative criteria. Therefore, it is best to use linguistic values in the form of a scale in these criteria. In this paper fuzzy logic will be used when choosing a supplier. In this case, the interval fuzzy logic will be used. When choosing a supplier, subjective assessments of the importance of particular criteria will be used and will be evaluated by individual vendors according to these criteria. In order to determine the weights of the supplier selection criteria, the interval fuzzy AHP (IVFS AHP) method is selected, which performs the subjective determination of the weight of the criterion. The IVFS AHP method works on comparing pairs of criteria and alternatives. Due to the fact that there would be too many pairs to compare each of the alternative suppliers according to the individual criterion with the IVFS AHP method, the interval fuzzy TOPSIS (IVFS TOPSIS) method will also be used. IVFS TOPSIS is based on the concept that a particular alternative should have the shortest distance from the positive ideal solution and the longest distance from the negative ideal solution ( $\mathrm{Lu}$ et al, 2007). In doing so, the best alternative is closest to the ideal positive solution, that is, the longest of the ideal negative solution. Since this study uses fuzzy logic when choosing a supplier, it is necessary to look at similar works that deal with this topic. Zeydan et al, (2011) used fuzzy AHP (FAHP), fuzzy TOPSIS (FTOPSIS) and DEA method for selecting suppliers in the automotive industry. Using the FAHP method they determined the weights of the criteria, with the FTOPSIS method they ranged the criteria while the DEA method was used to establish compliance with the criteria of individual suppliers. Kabir (2012) used FAHP to determine the weights of the criteria while with TOPSIS method he was assessing and selecting a logistics service provider, using three-fold fuzzy numbers. Kannan et al, (2013) ranked suppliers in the Green Supply Chain System. In doing so, they used FAHP to determine the weights of the criteria, FTOPSIS for determining the rank of the supplier's rankings and with the multi- 
A New Way of Applying Interval Fuzzy Logic in Group Decision Making for Supplier Selection

point programming methods performed the verification of meeting the criteria for certain suppliers. Junior et al, (2014) carried out the ranking of suppliers in the automotive industry by applying FAHP to determine the weights of the criteria, and the FTOPSIS method was used to determine the ranking order. Stević et al, (2016) used the FAHP and TOPSIS method in the selection of suppliers. FAHP was used to determine the weight of the criteria and the TOPSIS method for ranking suppliers. In this paper FAHP method will be used to determine the weights of the criteria, using interval fuzzy logic, while the FTOPSIS method will be used to rank the suppliers. Expert judgment will also be used to determine the weights of the criteria and for evaluating suppliers according to given criteria through linguistic values. In order to explain on a practical example a new approach to using interval fuzzy logic, it is first necessary to treat the concept of interval fuzzy logic theoretically and to explain the methods used. In order to make it easier to apply this methodology, the simplification of the IVFS AHP method, as well as the IVFS TOPSIS method, has been carried out in this paper. Therefore, the second part of the paper explains the interval fuzzy logic. The third part explains the IVFS AHP method, and in the fourth part, the IVFS TOPSIS method is explained. The fifth part is in charge of a new approach of applying interval logic on a real example of supplier selection. In the sixth part, the sensitivity analysis was carried out and the most important conclusions were derived.

\section{Interval fuzzy logic}

When we use the theory of fuzzy sets it is very difficult for the decision maker (DM) to precisely define his opinion in the interval $[0,1]$. For this reason, it is better to form the opinion using linguistic value, and through the fuzzy logic to transform it into an interval [0,1]. Interval-valued fuzzy (IVFS) was first used in Gorzalczany (1987). After that, this approach is used in other papers. The application of this approach is very diverse and it is increasingly used in practice (Ghorabaee et al, 2016), so it is necessary to define the interval fuzzy logic.

Based on the Gorzalczany's approach (1987), the basics of interval fuzzy logic were derived. The use of IVFS is defined in the interval $(-\infty,+\infty)$ and the following relations are given:

$$
\begin{aligned}
& A=\left\{\left(x,\left[\mu_{A}^{L}(x), \mu_{A}^{U}(x)\right]\right\}\right. \\
& \mu_{A}^{L}, \mu_{A}^{U}: X \rightarrow[0,1] \forall x \in X, \mu_{A}^{L} \leq \mu_{A}^{U} \\
& \bar{\mu}_{A}(x)=\left[\mu_{A}^{L}(x), \mu_{A}^{U}(x)\right] \\
& A=\left\{\left(x, \bar{\mu}_{A}(x)\right)\right\}, x \in(-\infty, \infty)
\end{aligned}
$$

Where is $\mu_{A}^{L}$ the lower limit of membership degree and $\mu_{A}^{U}$ the upper limit of membership degree to the fuzzy function. 
Bearing in mind the two boundaries of the interval fuzzy logic $N_{x}=\left[N_{x}^{-} ; N_{x}^{+}\right]$ and $M_{y}=\left[M_{y}^{-} ; M_{y}^{+}\right]$the following definitions are set:

Definition 1 The basic mathematical operations between these sets in the interval fuzzy logic are:

Addition and Subtraction of IVFN numbers:

$\tilde{N} \pm \tilde{M}=\left[\left(N_{1}, N_{1}^{*}\right) ; N_{2} ;\left(N_{3}^{*}, N_{3}\right)\right] \pm\left[\left(M_{1}, M_{1}^{*}\right) ; M_{2} ;\left(M_{3}^{*}, M_{3}\right)\right]=$
$\left[\left(N_{1} \pm M_{1}, N_{1}^{*} \pm M_{1}^{*}\right), N_{2} \pm M_{2} ;\left(N_{3}^{*} \pm M_{3}^{*}, N_{3} \pm M_{3}\right)\right]$

Multiplication of fuzzy numbers:

$\tilde{N} \times \tilde{M}=\left[\left(N_{1}, N_{1}^{*}\right) ; N_{2} ;\left(N_{3}^{*}, N_{3}\right)\right] \times\left[\left(M_{1}, M_{1}^{*}\right) ; M_{2} ;\left(M_{3}^{*}, M_{3}\right)\right]=$ $\left[\left(N_{1} \times M_{1}, N_{1}^{*} \times M_{1}^{*}\right), N_{2} \times M_{2} ;\left(N_{3}^{*} \times M_{3}^{*}, N_{3} \times M_{3}\right)\right]$

Division of fuzzy numbers:

$\tilde{N} \div \tilde{M}=\left[\left(N_{1}, N_{1}^{*}\right) ; N_{2} ;\left(N_{3}^{*}, N_{3}\right)\right] \div\left[\left(M_{1}, M_{1}^{*}\right) ; M_{2} ;\left(M_{3}^{*}, M_{3}\right)\right]=$ $\left[\left(N_{1} \div M_{3}, N_{1}^{*} \div M_{3}^{*}\right), N_{2} \div M_{2} ;\left(N_{3}^{*} \div M_{1}^{*}, N_{3} \div M_{1}\right)\right]$

Multiplication by plain number

$q \times \tilde{N}=q \times\left[\left(N_{1}, N_{1}^{*}\right) ; N_{2} ;\left(N_{3}^{*}, N_{3}\right)\right]=\left[\left(q \times N_{1}, q \times N_{1}^{*}\right) ; q \times N_{2} ;\left(q \times N_{3}^{*}, q \times N_{3}\right)\right](5)$

Division by plain number

$$
\tilde{N} \div q=\left[\left(N_{1}, N_{1}^{*}\right) ; N_{2} ;\left(N_{3}^{*}, N_{3}\right)\right] \div q,=\left[\left(\frac{N_{1}}{q}, \frac{N_{1}^{*}}{q}\right) ; \frac{N_{2}}{q} ;\left(\frac{N_{3}^{*}}{q}, \frac{N_{3}}{q}\right)\right]
$$

Definition 2 The average of two IVFS (Gorzalczany, 1987) is defined as the minimum of the lower and upper limits of the interval. Two intervals $[0,1]$ and $M_{y}=\left[M_{y}^{-} ; M_{y}^{+}\right] \subset[0,1]$ are given, the minimum value for both these intervals is: $K=\operatorname{Min}\left(N_{x}, M_{y}\right)=\left[\operatorname{Min}\left(N_{x}^{-}, M_{y}^{-}\right), \operatorname{Min}\left(N_{x}^{+}, M_{y}^{+}\right)\right]$.

Definition 3 The average of two IVFS (Mousavi et al, 2013) is defined as the maximum of the lower and upper limits of the interval. Two intervals are given: $[0,1]$ and $M_{y}=\left[M_{y}^{-} ; M_{y}^{+}\right] \subset[0,1]$, where the maximum value for both these intervals is: $K=\operatorname{Max}\left(N_{x}, M_{y}\right)=\left[\operatorname{Max}\left(N_{x}^{-}, M_{y}^{-}\right), \operatorname{Max}\left(N_{x}^{+}, M_{y}^{+}\right)\right]$.

Definition 4 Absolute value: $\left|N_{x}\right|=\operatorname{Max}\left\{\left|N_{x}^{-}\right|,\left|N_{x}^{+}\right|\right\}$ 
A New Way of Applying Interval Fuzzy Logic in Group Decision Making for Supplier Selection

Definition 5 Let the $\tilde{N}$ and $\tilde{M}$ be two triangles IVFS where it is $\tilde{N}=\left[\left(N_{1}, N_{1}^{*}\right) ; N_{2} ;\left(N_{3}^{*}, N_{3}\right)\right]$ and $\tilde{M}=\left[\left(M_{1}, M_{1}^{*}\right) ; M_{2} ;\left(M_{3}^{*}, M_{3}\right)\right]$. These IVFS can be represented as follows:

$h(\tilde{N})=\frac{N_{1}+N_{1}^{*}+2 N_{2}+N_{3}^{*}+N_{3}}{6}$

i $h(\tilde{M})=\frac{M_{1}+M_{1}^{*}+2 M_{2}+M_{3}^{*}+M_{3}}{6}$

It can be said that it is $\tilde{N}>\tilde{M}$ if it is $h(\tilde{N})>h(\tilde{M})$.

In this paper, the following linguistic values of IVFS will be used to determine the importance of alternatives for individual criteria (Table 1) and for determining the weights of the criteria (Table 2).

Table 1. Definitions of linguistic variables for the ratings

\begin{tabular}{ll} 
Very Poor (VP) & {$[(0,0) ; 0 ;(1,1.5)]$} \\
Poor (P) & {$[(0,0.5) ; 1 ;(2.5,3.5)]$} \\
Medium Poor (MP) & {$[(0,1.5) ; 3 ;(4.5,5.5)]$} \\
Medium (F) & {$[(2.5,3.5) ; 5 ;(6.5,7.5)]$} \\
Medium Good (MG) & {$[(4.5,5.5) ; 7 ;(8,9.5)]$} \\
Good (G) & {$[(5.5,7.5) ; 9 ;(9.5,10)]$} \\
Very Good (VG) & {$[(8.5,9.5) ; 10 ;(10,10)]$} \\
\hline
\end{tabular}

Table 2. Definitions of linguistic variables for the importance of each criterion

\begin{tabular}{lc}
\hline Equally (E) & {$[(1,1) ; 1 ;(1,1)]$} \\
Very Low Strong (LS) & {$[(1,1.5) ; 2 ;(2.5,3)]$} \\
Slightly Strong (SS) & {$[(2,2.5) ; 3 ;(3.5,4)]$} \\
Medium Strong (MS) & {$[(3,3.5) ; 4 ;(4.5,5)]$} \\
Fairly Strong (FS) & {$[(4,4.5) ; 5 ;(5.5,6)]$} \\
Preferred Strong (PS) & {$[(5,5.5) ; 6 ;(6.5,7)]$} \\
Very Strong (VS) & {$[(6,6.5) ; 7 ;(7.5,8)]$} \\
Very High Strong (VH) & {$[(7,7.5) ; 8 ;(8.5,9)]$} \\
Absolutely Strong (AS) & {$[(8,8.5) ; 9 ;(9,9)]$} \\
\hline
\end{tabular}

\section{IVF AHP method}

The AHP method was developed by Saaty in 1980. It is based on the comparison of pairs of alternatives, where the decision maker expresses the intensity, weight of the preferences of one alternative relative to the other, within the essential criteria (Puška, 2011). In the same way, the criteria are compared according to their own preferences and their intensity. Making a decision using the AHP method is applied using assessment of the weight of the criterion (Turskis and Zavadskas, 2010). In order to better contribute to solving the uncertainty and undetermined in decision-making, the AHP method has been integrated with an interactive fuzzy logic. Kahraman et al, (2012) and Sari et al, (2013) were the first studies that 
focused on the use of interval fuzzy logic with the AHP method. In this paper presented the application of the IVFS AHP method that will be used in decision making in the group. The procedure for applying the IVFS AHP method consists of the following steps:

Steps 1 Defining a problem and setting a goal.

Step 2 Structuring the problem, setting the target to the top, the criteria in the middle and alternatives to the bottom of the structure.

Step 3 Comparison of criteria or alternatives in pairs and the assignment of linguistic values presented in Table 2. Based on these comparisons, fuzzy pairwise comparison matrices are formed as following (Oztaysi, 2015):

$$
\tilde{\tilde{A}}=\left[\begin{array}{cccc}
1 & \tilde{\tilde{a}}_{12} & \Lambda & \tilde{\tilde{a}}_{1 n} \\
\tilde{\tilde{a}}_{21} & 1 & \Lambda & \tilde{\tilde{a}}_{2 n} \\
\mathrm{M} & \mathrm{M} & \mathrm{O} & \mathrm{M} \\
\tilde{\tilde{a}}_{n 1} & \tilde{\tilde{a}}_{n 2} & \Lambda & 1
\end{array}\right]=\left[\begin{array}{cccc}
1 & \tilde{\tilde{a}}_{12} & \Lambda & \tilde{\tilde{a}}_{1 n} \\
1 / \tilde{\tilde{a}}_{12} & 1 & \Lambda & \tilde{\tilde{a}}_{2 n} \\
\mathrm{M} & \mathrm{M} & \mathrm{O} & \mathrm{M} \\
1 / \tilde{\tilde{a}}_{1 n} & 1 / \tilde{\tilde{a}}_{2 n} & \Lambda & 1
\end{array}\right]
$$

Where:

$$
1 / a=\left(\left(\frac{1}{a_{13}^{u}}, \frac{1}{a_{12}^{u}}, \frac{1}{a_{11}^{u}} ; H_{1}\left(a_{12}^{u}\right), H_{2}\left(a_{13}^{u}\right)\right),\left(\frac{1}{a_{23}^{u}}, \frac{1}{a_{22}^{u}}, \frac{1}{a_{21}^{u}} ; H_{1}\left(a_{22}^{u}\right), H_{2}\left(a_{23}^{u}\right)\right)\right)
$$

Step 4 Transformation of linguistic values into fuzzy numbers. Since this is an interval fuzzy logic in the transformation of linguistic values of the weights of the criteria, two matrices of decision are formed for each of the intervals:

$$
\begin{aligned}
A & =\left[\begin{array}{cccc}
1 & a_{12}, b_{12}, c_{12}^{*} & \Lambda & a_{1 n}, b_{1 n}, c_{1 n}^{*} \\
1 / c_{12}^{*}, 1 / b_{12}, 1 / a_{12} & 1 & \Lambda & a_{2 n}, b_{2 n}, c_{2 n}^{*} \\
\mathrm{M} & \mathrm{M} & \mathrm{O} & \mathrm{M} \\
1 / c_{1 n}^{*}, 1 / b_{1 n}, 1 / a_{1 n} & 1 / c_{2 n}^{*}, 1 / b_{2 n}, 1 / a_{2 n} & \Lambda & 1
\end{array}\right] \\
A^{\prime} & =\left[\begin{array}{cccc}
1 & a_{12}^{*}, b_{12}, c_{12} & \Lambda & a_{1 n}^{*}, b_{1 n}, c_{1 n} \\
1 / c_{12}, 1 / b_{12}, 1 / a_{12}^{*} & 1 & \Lambda & a_{2 n}^{*}, b_{2 n}, c_{2 n} \\
\mathrm{M} & \mathrm{M} & \mathrm{O} & \mathrm{M} \\
1 / c_{1 n}, 1 / b_{1 n}, 1 / a_{1 n}^{*} & 1 / c_{2 n}, 1 / b_{2 n}, 1 / a_{2 n}^{*} & \Lambda & 1
\end{array}\right]
\end{aligned}
$$

Formed matrices show that in the case of reciprocal values, the order of fuzzy numbers changes, because if the fuzzy number function does not change, the first fuzzy number would be the largest and the third the smallest. In this way, a membership function is formed which on the following example looks like this: $1 / c_{12} \leq 1 / b_{12} \leq 1 / a_{12}^{*}$.

Step 5 Normalization of the matrix. 
A New Way of Applying Interval Fuzzy Logic in Group Decision Making for Supplier Selection

In this step, the normalization of the decision matrices is carried out, which can be done in different ways, and in this example, the classic normalization used by Saaty (1980), when presenting this method, will be taken.

$r_{i j}=\frac{a_{i j}}{\sum_{j=1}^{n} a_{i j}}, \frac{b_{i j}}{\sum_{j=1}^{n} b_{i j}}, \frac{c_{i j}}{\sum_{j=1}^{n} c_{i j}}$

Step 6 Calculating the weight of a criterion or an alternative.

After that, the geometric mean for the rows representing individual criteria, or alternatives, is calculated. The geometric mean is done as follows:

$w_{i a}=\sqrt[n]{a_{i 1} \cdot a_{i 2} \cdot \mathrm{K} \cdot a_{i n}}$

Using this formula, we calculate the weight values for all fuzzy numbers. After that, the denazification of weights is done using the following formula, and a crisp number is obtained (Kahraman et al, 2014):

$A=\frac{g_{i j}+4 h_{i j}+l_{i j}}{6}$

The next step is to calculate the total weight that is obtained as the average weights of intervals:

$w=\frac{w A+w A^{*}}{2}$

\section{IVFS TOPSIS method}

The TOPSIS method was first applied by Hwang and Yoon (1981). The basis of this method is the principle that the best alternative is the one with the shortest distance from the Positive Ideal Solution (PIS), i.e. the greatest distance from the Negative-Ideal Solution (NIS). The PIS is the ideal solution where are the smallest costs but the biggest benefit, while NIS is the worst solution where are the highest costs but least benefit. Based on this approach, Chen and Hwang (1992) developed the approach to applying the TOPSIS method in a fuzzy set.

In this paper the following steps will be applied when using the TOPSIS method in IVFS.

Steps 1 Normalization of decision matrix. This is the first step of each method for multi-criteria analysis (MCA). In this paper, the normalization of TYPE 1 or 'the free linear normalization' will be used. With this method, the criteria of benefits are shared with the maximum value of the membership function, while the criteria of costs are divided with a minimum value. Based on this, the following membership function was given: $\tilde{x}=\left[\left(a_{i j}, a_{i j}^{*}\right) ; b_{i j} ;\left(\mathrm{c}_{\mathrm{ij}}^{*} ; c_{i j}\right)\right]$.

Using the normalization proposed by Chen (2000), it can be calculated as: 


$$
\begin{aligned}
& \tilde{r}_{i j}=\left[\left(\frac{a_{i j}}{c_{j}^{+}}, \frac{a_{i j}^{*}}{c_{j}^{+}}\right) ; \frac{b_{i j}}{c_{j}^{+}} ;\left(\frac{c_{i j}^{*}}{c_{j}^{+}}, \frac{c_{i j}}{c_{j}^{+}}\right)\right], i=1, \ldots, n, j \in \Omega_{b} \\
& \tilde{r}_{i j}=\left[\left(\frac{a_{j}^{-}}{c_{i j}^{*}}, \frac{a_{j}^{-}}{c_{i j}}\right) ; \frac{a_{j}^{-}}{b_{i j}} ;\left(\frac{a_{j}^{-}}{a_{i j}}, \frac{a_{j}^{-}}{a_{i j}^{*}}\right)\right], i=1, \ldots, n, j \in \Omega_{c}
\end{aligned}
$$

Where it is

$c_{j}^{+}=\operatorname{Maxc}_{i j}, j \in \Omega_{b}$

$a_{j}^{-}=\operatorname{Mina}_{i j}, j \in \Omega_{c}$

Further steps will be explained on the basis of a corrected approach from Ashtiani et al, (2009).

Step 2 Multiplication of a normalized matrix.

In this step, the normalized values of the decision matrix with weighted values are multiplied and the following form is made:

$\tilde{v}_{i j}=\left[\left(\tilde{r}_{1 i j} \times \tilde{w}_{1 j}, \tilde{r}_{1 i j}^{*} \times \tilde{w}_{1 j}^{* \prime}\right) ; \tilde{r}_{2 i j} \times \tilde{w}_{2 j} ;\left(\tilde{r}_{3 i j}^{*} \times \tilde{w}_{3 j}^{* \prime}, r_{31 i} \times \tilde{w}_{3 j}\right)\right]=$

$=\left[\left(g_{i j}, g_{i j}^{*}\right) ; h_{i j} ;\left(l_{i j}^{*}, l_{i j}\right)\right]$

Step 3 Defining an ideally positive and negative solution.

The PIS can be defined as:

$$
A^{+}=\left\{v_{1}^{+}, \mathrm{K}, v_{n}^{+}\right\}=\left\{\left(\max _{j} v_{i j} \mid i \in I\right),\left(\min _{j} v_{i j} \mid i \in J\right)\right\}
$$

NIS can be defined as:

$A^{-}=\left\{v_{1}^{-}, \mathrm{K}, v_{n}^{-}\right\}=\left\{\left(\min _{j} v_{i j} \mid i \in I\right),\left(\max _{j} v_{i j} \mid i \in J\right)\right\}$

Step 4 Determining the distance of alternatives from ideal solutions.

In this step the n-dimensional Euclidean distances of all alternatives of an ideally positive and ideally negative solution are calculated by means of relations.

$D^{-}(\tilde{N}, \tilde{M})=\sqrt{\frac{1}{3} \sum_{i=1}^{3}\left[\left(N_{x i}^{-}-M_{y i}^{-}\right)^{2}\right]}$

$D^{+}(\tilde{N}, \tilde{M})=\sqrt{\frac{1}{3} \sum_{i=1}^{3}\left[\left(N_{x i}^{+}-M_{y i}^{+}\right)^{2}\right]}$

Where $D^{-}(\tilde{N}, \tilde{M})$ and $D^{+}(\tilde{N}, \tilde{M})$ are the primary and secondary distant measure, respectively. Thereby, distance of each alternative from the ideal alternative $\left[D_{i 1}^{+}, D_{i 2}^{+}\right]$can be currently calculated, where (Ashtiani et al, 2009): 
A New Way of Applying Interval Fuzzy Logic in Group Decision Making for Supplier Selection

$$
\begin{aligned}
& D_{i 1}^{+}=\sum_{j=1}^{m} \sqrt{\frac{1}{3}\left[\left(g_{i j}-g_{j}^{+}\right)^{2}+\left(h_{i j}-h_{j}^{+}\right)^{2}+\left(l_{i j}^{*}-l_{j}^{*+}\right)^{2}\right]} \\
& D_{i 2}^{+}=\sum_{j=1}^{m} \sqrt{\frac{1}{3}\left[\left(g_{i j}^{*}-g_{j}^{*+}\right)^{2}+\left(h_{i j}-h_{j}^{+}\right)^{2}+\left(l_{i j}-l_{j}^{+}\right)^{2}\right]}
\end{aligned}
$$

Simultaneously, for negative ideal solutions the following terms are followed:

$$
\begin{aligned}
& D_{i 1}^{-}=\sum_{j=1}^{m} \sqrt{\frac{1}{3}\left[\left(g_{i j}-g_{j}^{-}\right)^{2}+\left(h_{i j}-h_{j}^{-}\right)^{2}+\left(l_{i j}^{*}-l_{j}^{*-}\right)^{2}\right]} \\
& D_{i 2}^{-}=\sum_{j=1}^{m} \sqrt{\frac{1}{3}\left[\left(g_{i j}^{*}-g_{j}^{*-}\right)^{2}+\left(h_{i j}-h_{j}^{-}\right)^{2}+\left(l_{i j}-l_{j}^{-}\right)^{2}\right]}
\end{aligned}
$$

Applying this principle, less data is lost than combining these two formulas into one.

Step 5 Determining the relative proximity of an alternative to an ideal solution.

Since in this example we have two intervals and two solutions, it is necessary to calculate the average value of the solution of the relative proximity of the alternative to the ideal solution for both intervals. Relative proximity calculations are calculated as follows:

$$
C C_{1}=\frac{D_{i 1}^{-}}{D_{i 1}^{+}+D_{i 1}^{-}}, C C_{2}=\frac{D_{i 2}^{-}}{D_{i 2}^{+}+D_{i 2}^{-}}
$$

And the final solution is calculated by finding the average of these two solutions:

$$
C C_{i}^{*}=\frac{C C_{1}+C C_{2}}{2}
$$

\section{Integrated model to the supplier selection problem}

The integrated model of the supplier selection problem will be done on the example from the practice. For example, a paper manufacturing company will be used. The biggest problem with paper production is of ecological nature. Therefore, it is necessary to pay attention to suppliers during the production of paper and try to reduce ecological problems. Suppliers can supply materials, equipment and services that will reduce the occurrence of environmental risks in the production of paper. Since these decisions require long-term investment of the company, it is important to select a supplier who will help him in solving these production problems. The proposed supplier selection model was implemented in the mentioned company. The basic task of this model is to use a group decision to select a supplier with which the company could establish long-term partnership relations. This is why a detailed survey was conducted through the distribution of questionnaires to the managers of this company. On the basis of the obtained data, the criteria for the selection of the supplier were 
reduced. After comparing all the criteria and alternatives, a comparative questionnaire was developed to determine the weights of the criteria used for the AHP method and the determination of the linguistic values of each supplier for individual criteria was made. Certain criteria are presented in Table 3. The goal of this model is to select a supplier that best meets the set decision goals. The proposed model is presented in Figure 1.

\begin{tabular}{|c|c|}
\hline & Decision of the selection of supplier \\
\hline \hline & Determination of the nine criteria with which suppliers will be \\
evaluated
\end{tabular}

Figure 1. Proposed approach of supplier selection

Table 3. Criteria for the selection of suppliers

\begin{tabular}{|c|c|c|}
\hline & Criteria & Definition \\
\hline $\mathrm{C}_{1}$ & $\begin{array}{l}\text { Additional discount } \\
\text { on quantity }\end{array}$ & $\begin{array}{l}\text { Possibility to obtain a lower price per unit of production if a } \\
\text { larger quantity is purchased. }\end{array}$ \\
\hline $\mathrm{C}_{2}$ & $\begin{array}{l}\text { Certification of the } \\
\text { product }\end{array}$ & $\begin{array}{l}\text { The certification implies confirmation by an independent } \\
\text { organization that the products conform to certain normative } \\
\text { documents. }\end{array}$ \\
\hline $\mathrm{C}_{3}$ & Price & Price is the value of a product, goods, or service. \\
\hline $\mathrm{C}_{4}$ & Quality & $\begin{array}{l}\text { Quality is the degree to which a set of product characteristics } \\
\text { meets customer requirements. }\end{array}$ \\
\hline $\mathrm{C}_{5}$ & Warranty period & $\begin{array}{l}\text { The warranty period is the time for which the manufacturer } \\
\text { guarantees the value of the warranty on the products. }\end{array}$ \\
\hline $\mathrm{C}_{6}$ & Method of payment & Methods in which the payment to the supplier can be made. \\
\hline $\mathrm{C}_{7}$ & Reputations & $\begin{array}{l}\text { Reputation marks the general opinion of the supplier, which } \\
\text { relates to his reputation. }\end{array}$ \\
\hline $\mathrm{C}_{8}$ & Delivery time & $\begin{array}{l}\text { It represents the deadline for when the supplier is going to } \\
\text { deliver his products or services. }\end{array}$ \\
\hline $\mathrm{C}_{9}$ & Reliability & $\begin{array}{l}\text { Reliability is the probability that the supplier will perform all } \\
\text { the tasks envisaged within a specified period of time. }\end{array}$ \\
\hline
\end{tabular}


A New Way of Applying Interval Fuzzy Logic in Group Decision Making for Supplier Selection

Based on the established criteria, it can be concluded that $\mathrm{C}_{3}$ - price and $\mathrm{C}_{8}$ delivery time, are the cost criteria and it is desirable that these values be as low as possible, while other criteria are benefit criteria, i.e. it is desirable that their value be as high as possible. All calculations were done in MS Excel. Since the first phase has been completed and criteria and suppliers were selected, it is necessary to determine the weights of the criteria using the IVFS AHP method. Since the opinions of the three decision makers were taken (DMs), in Table 4 are presented their preference values of the criteria by means of the linguistic variables which are presented in Table 2.

Table 4. Comparison of criteria by pairs for each decision maker

\begin{tabular}{|c|c|c|c|c|c|c|c|c|c|}
\hline DM1 & $\mathrm{C}_{1}$ & $\mathrm{C}_{2}$ & $\mathrm{C}_{3}$ & $\mathrm{C}_{4}$ & $\mathrm{C}_{5}$ & $\mathrm{C}_{6}$ & $\mathrm{C}_{7}$ & $\mathrm{C}_{8}$ & $\mathrm{C}_{9}$ \\
\hline $\mathrm{C}_{1}$ & $\mathrm{E}$ & SS & $1 / \mathrm{SS}$ & 1/MS & MS & PS & MS & SS & FS \\
\hline $\mathrm{C}_{2}$ & $1 / \mathrm{SS}$ & $\mathrm{E}$ & 1/MS & 1/FS & SS & $\mathrm{FS}$ & SS & $\mathrm{E}$ & MS \\
\hline $\mathrm{C}_{3}$ & $\mathrm{SS}$ & MS & E & $1 / \mathrm{SS}$ & FS & VS & FS & SS & PS \\
\hline $\mathrm{C}_{4}$ & MS & FS & SS & E & PS & VH & PS & FS & VS \\
\hline $\mathrm{C}_{5}$ & $1 / \mathrm{MS}$ & 1/SS & 1/FS & 1/PS & $\mathrm{E}$ & MS & $\mathrm{E}$ & $1 / \mathrm{SS}$ & SS \\
\hline $\mathrm{C}_{6}$ & 1/PS & $1 / \mathrm{FS}$ & $1 / \mathrm{VS}$ & $1 / \mathrm{VH}$ & 1/MS & $\mathrm{E}$ & 1/MS & 1/FS & $1 / \mathrm{SS}$ \\
\hline $\mathrm{C}_{7}$ & 1/MS & 1/SS & 1/FS & 1/PS & $\mathrm{E}$ & MS & $\mathrm{E}$ & $1 / \mathrm{SS}$ & SS \\
\hline $\mathrm{C}_{8}$ & $1 / \mathrm{SS}$ & $\mathrm{E}$ & $1 / \mathrm{SS}$ & 1/FS & SS & FS & SS & E & MS \\
\hline $\mathrm{C}_{9}$ & $1 / \mathrm{FS}$ & $1 / \mathrm{MS}$ & 1/PS & 1/VS & $1 / \mathrm{SS}$ & SS & $1 / \mathrm{SS}$ & 1/MS & E \\
\hline DM2 & $\mathrm{C}_{1}$ & $\mathrm{C}_{2}$ & $\mathrm{C}_{3}$ & $\mathrm{C}_{4}$ & $\mathrm{C}_{5}$ & $\mathrm{C}_{6}$ & $\mathrm{C}_{7}$ & $\mathrm{C}_{8}$ & $\mathrm{C}_{9}$ \\
\hline $\mathrm{C}_{1}$ & $E$ & SS & $1 / \mathrm{VS}$ & $1 / \mathrm{VH}$ & MS & FS & MS & SS & FS \\
\hline $\mathrm{C}_{2}$ & $1 / \mathrm{SS}$ & $\mathrm{E}$ & $1 / \mathrm{VS}$ & $1 / \mathrm{VH}$ & SS & MS & SS & $1 / \mathrm{MS}$ & MS \\
\hline $\mathrm{C}_{3}$ & VS & VS & $\mathrm{E}$ & $1 / \mathrm{MS}$ & MS & PS & FS & MS & FS \\
\hline $\mathrm{C}_{4}$ & VH & VH & MS & $\mathrm{E}$ & FS & VS & PS & FS & PS \\
\hline $\mathrm{C}_{5}$ & $1 / \mathrm{MS}$ & $1 / \mathrm{SS}$ & 1/MS & 1/FS & $\mathrm{E}$ & SS & SS & 1/FS & VL \\
\hline $\mathrm{C}_{6}$ & $1 / \mathrm{FS}$ & 1/MS & 1/PS & 1/VS & $1 / \mathrm{SS}$ & $\mathrm{E}$ & $1 / \mathrm{FS}$ & 1/PS & $1 / \mathrm{MS}$ \\
\hline $\mathrm{C}_{7}$ & $1 / \mathrm{MS}$ & $1 / \mathrm{SS}$ & $1 / \mathrm{FS}$ & 1/PS & $1 / \mathrm{SS}$ & FS & $\mathrm{E}$ & 1/FS & SS \\
\hline $\mathrm{C}_{8}$ & $1 / \mathrm{SS}$ & MS & 1/MS & 1/FS & FS & PS & FS & $\mathrm{E}$ & MS \\
\hline $\mathrm{C}_{9}$ & 1/FS & 1/MS & 1/FS & 1/PS & $1 / \mathrm{VL}$ & MS & $1 / \mathrm{SS}$ & 1/MS & $\mathrm{E}$ \\
\hline DM3 & $\mathrm{C}_{1}$ & $\mathrm{C}_{2}$ & $\mathrm{C}_{3}$ & $\mathrm{C}_{4}$ & $\mathrm{C}_{5}$ & $\mathrm{C}_{6}$ & $\mathrm{C}_{7}$ & $\mathrm{C}_{8}$ & $\mathrm{C}_{9}$ \\
\hline $\mathrm{C}_{1}$ & $\mathrm{E}$ & $\mathrm{MS}$ & $1 / \mathrm{MS}$ & $1 / \mathrm{MS}$ & $\overline{F S}$ & VS & FS & MS & PS \\
\hline $\mathrm{C}_{2}$ & $1 / \mathrm{MS}$ & $\mathrm{E}$ & 1/FS & $1 / \mathrm{FS}$ & SS & FS & SS & $1 / \mathrm{VS}$ & MS \\
\hline $\mathrm{C}_{3}$ & MS & FS & $\mathrm{E}$ & $\mathrm{E}$ & PS & VH & PS & FS & VS \\
\hline $\mathrm{C}_{4}$ & MS & FS & $\mathrm{E}$ & $\mathrm{E}$ & PS & VH & PS & FS & VS \\
\hline $\mathrm{C}_{5}$ & $1 / \mathrm{FS}$ & $1 / \mathrm{SS}$ & 1/PS & 1/PS & $\mathrm{E}$ & MS & VL & $1 / \mathrm{SS}$ & SS \\
\hline $\mathrm{C}_{6}$ & 1/VS & $1 / \mathrm{FS}$ & $1 / \mathrm{VH}$ & $1 / \mathrm{VH}$ & 1/MS & $\mathrm{E}$ & $1 / \mathrm{MS}$ & 1/FS & $1 / \mathrm{SS}$ \\
\hline $\mathrm{C}_{7}$ & 1/FS & $1 / \mathrm{SS}$ & 1/PS & 1/PS & $1 / \mathrm{VL}$ & MS & $\mathrm{E}$ & $1 / \mathrm{SS}$ & SS \\
\hline $\mathrm{C}_{8}$ & 1/MS & VS & 1/FS & 1/FS & SS & FS & SS & $\mathrm{E}$ & MS \\
\hline $\mathrm{C}_{9}$ & 1/PS & 1/MS & 1/VS & $1 / \mathrm{VS}$ & $1 / \mathrm{SS}$ & SS & 1/SS & $1 / \mathrm{MS}$ & $\mathrm{E}$ \\
\hline
\end{tabular}

Since there are three DMs, the DM1 example will present the methodology for implementing the IVFS AHP method. Based on linguistic values, the transformation of linguistic values into fuzzy numbers in the form of an interval is made. Therefore, two matrices for each of the intervals are formed. After the matrix of criteria is established for both intervals, normalization is performed, and 
Adis Puška, Safet Kozarević, Željko Stević, Jasmin Stovrag

the geometric mean for each fuzzy number is calculated. The same procedure is carried out with all DMs. By applying this procedure, the weights of the criteria for each DMs was determined (Table 5).

Table 5. The weights of the criteria for the decision maker

\begin{tabular}{|c|c|c|c|c|c|c|c|c|c|}
\hline DM1 & \multicolumn{3}{|c|}{$\begin{array}{l}\text { Fuzzy weight for } \\
\text { the interval A }\end{array}$} & wA & \multicolumn{3}{|c|}{$\begin{array}{l}\text { Fuzzy weight for } \\
\text { the interval } A^{\prime}\end{array}$} & $\mathrm{wA}^{\prime}$ & W \\
\hline $\mathrm{C}_{1}$ & 0.14 & 0.14 & 0.15 & 0.144 & 0.14 & 0.15 & 0.15 & 0.146 & 0.145 \\
\hline $\mathrm{C}_{2}$ & 0.09 & 0.09 & 0.09 & 0.086 & 0.08 & 0.09 & 0.09 & 0.085 & 0.085 \\
\hline $\mathrm{C}_{3}$ & 0.21 & 0.21 & 0.21 & 0.214 & 0.22 & 0.22 & 0.22 & 0.217 & 0.215 \\
\hline $\mathrm{C}_{4}$ & 0.33 & 0.33 & 0.31 & 0.328 & 0.34 & 0.33 & 0.33 & 0.334 & 0.331 \\
\hline $\mathrm{C}_{5}$ & 0.05 & 0.05 & 0.05 & 0.047 & 0.04 & 0.05 & 0.04 & 0.045 & 0.046 \\
\hline $\mathrm{C}_{6}$ & 0.02 & 0.02 & 0.02 & 0.019 & 0.02 & 0.02 & 0.02 & 0.018 & 0.018 \\
\hline $\mathrm{C}_{7}$ & 0.05 & 0.05 & 0.05 & 0.047 & 0.06 & 0.06 & 0.06 & 0.058 & 0.052 \\
\hline $\mathrm{C}_{8}$ & 0.09 & 0.09 & 0.09 & 0.089 & 0.07 & 0.07 & 0.07 & 0.069 & 0.079 \\
\hline $\mathrm{C}_{9}$ & 0.03 & 0.03 & 0.03 & 0.029 & 0.03 & 0.03 & 0.03 & 0.027 & 0.028 \\
\hline DM2 & \multicolumn{3}{|c|}{$\begin{array}{c}\text { Fuzzy weight for } \\
\text { the interval A }\end{array}$} & wA & \multicolumn{3}{|c|}{$\begin{array}{l}\text { Fuzzy weight for } \\
\text { the interval } \mathrm{A}^{\prime}\end{array}$} & $\mathrm{wA}^{\prime}$ & $\mathrm{W}$ \\
\hline $\mathrm{C}_{1}$ & 0.15 & 0.15 & 0.15 & 0.151 & 0.15 & 0.15 & 0.15 & 0.153 & 0.152 \\
\hline $\mathrm{C}_{2}$ & 0.08 & 0.08 & 0.08 & 0.077 & 0.07 & 0.08 & 0.08 & 0.076 & 0.076 \\
\hline $\mathrm{C}_{3}$ & 0.23 & 0.23 & 0.23 & 0.231 & 0.24 & 0.23 & 0.23 & 0.233 & 0.232 \\
\hline $\mathrm{C}_{4}$ & 0.30 & 0.31 & 0.29 & 0.302 & 0.32 & 0.31 & 0.31 & 0.310 & 0.306 \\
\hline $\mathrm{C}_{5}$ & 0.05 & 0.05 & 0.06 & 0.052 & 0.05 & 0.05 & 0.05 & 0.052 & 0.052 \\
\hline $\mathrm{C}_{6}$ & 0.03 & 0.02 & 0.03 & 0.024 & 0.02 & 0.02 & 0.02 & 0.023 & 0.023 \\
\hline $\mathrm{C}_{7}$ & 0.04 & 0.04 & 0.04 & 0.041 & 0.05 & 0.05 & 0.05 & 0.051 & 0.046 \\
\hline $\mathrm{C}_{8}$ & 0.09 & 0.09 & 0.09 & 0.092 & 0.07 & 0.07 & 0.07 & 0.073 & 0.082 \\
\hline $\mathrm{C}_{9}$ & 0.03 & 0.03 & 0.03 & 0.031 & 0.03 & 0.03 & 0.03 & 0.029 & 0.030 \\
\hline DM3 & \multicolumn{3}{|c|}{$\begin{array}{c}\text { Fuzzy weight for } \\
\text { the interval A }\end{array}$} & wA & \multicolumn{3}{|c|}{$\begin{array}{l}\text { Fuzzy weight for } \\
\text { the interval } A^{\prime}\end{array}$} & $\mathrm{wA}^{\prime}$ & $\mathrm{w}$ \\
\hline $\mathrm{C}_{1}$ & 0.15 & 0.16 & 0.15 & 0.156 & 0.16 & 0.16 & 0.16 & 0.158 & 0.157 \\
\hline $\mathrm{C}_{2}$ & 0.07 & 0.07 & 0.07 & 0.072 & 0.07 & 0.07 & 0.08 & 0.073 & 0.072 \\
\hline $\mathrm{C}_{3}$ & 0.29 & 0.28 & 0.29 & 0.280 & 0.29 & 0.28 & 0.28 & 0.284 & 0.282 \\
\hline $\mathrm{C}_{4}$ & 0.29 & 0.28 & 0.29 & 0.280 & 0.29 & 0.28 & 0.28 & 0.284 & 0.282 \\
\hline $\mathrm{C}_{5}$ & 0.04 & 0.05 & 0.04 & 0.046 & 0.04 & 0.05 & 0.05 & 0.045 & 0.046 \\
\hline $\mathrm{C}_{6}$ & 0.02 & 0.02 & 0.02 & 0.017 & 0.02 & 0.02 & 0.02 & 0.017 & 0.017 \\
\hline $\mathrm{C}_{7}$ & 0.04 & 0.04 & 0.04 & 0.040 & 0.05 & 0.05 & 0.05 & 0.051 & 0.046 \\
\hline $\mathrm{C}_{8}$ & 0.08 & 0.08 & 0.08 & 0.083 & 0.06 & 0.06 & 0.06 & 0.063 & 0.073 \\
\hline $\mathrm{C}_{9}$ & 0.03 & 0.03 & 0.03 & 0.026 & 0.02 & 0.03 & 0.02 & 0.025 & 0.026 \\
\hline
\end{tabular}

Based on DM preference, it can be concluded that the most important criterion for choosing supplier $\mathrm{C}_{4}$ is the quality of products, then $\mathrm{C}_{3}$ - the price that is particularly different from other criteria. The least importance for all DMs was $\mathrm{C}_{6}$ payment method, then criterion $\mathrm{C}_{9}$ - reliability. It can be concluded that DMs equitably assigned criteria preferences and obtained similar weights. After calculating the weights of the criteria, it is necessary to evaluate suppliers with 
A New Way of Applying Interval Fuzzy Logic in Group Decision Making for Supplier Selection

linguistic values for each of the criteria. The evaluation of the suppliers is presented in Table 6 .

Table 6. Decision matrix for alternatives of every DM

\begin{tabular}{cccccccccc}
\hline DM1 & $\mathrm{C}_{1}$ & $\mathrm{C}_{2}$ & $\mathrm{C}_{3}$ & $\mathrm{C}_{4}$ & $\mathrm{C}_{5}$ & $\mathrm{C} 6$ & $\mathrm{C}_{7}$ & $\mathrm{C}_{8}$ & $\mathrm{C}_{9}$ \\
\hline $\mathrm{A}_{1}$ & $\mathrm{P}$ & $\mathrm{F}$ & $\mathrm{P}$ & $\mathrm{G}$ & $\mathrm{MG}$ & $\mathrm{MG}$ & $\mathrm{F}$ & $\mathrm{MP}$ & $\mathrm{P}$ \\
$\mathrm{A}_{2}$ & $\mathrm{~F}$ & $\mathrm{MP}$ & $\mathrm{F}$ & $\mathrm{MG}$ & $\mathrm{MG}$ & $\mathrm{F}$ & $\mathrm{P}$ & $\mathrm{F}$ & $\mathrm{MP}$ \\
$\mathrm{A}_{3}$ & $\mathrm{G}$ & $\mathrm{G}$ & $\mathrm{G}$ & $\mathrm{G}$ & $\mathrm{MG}$ & $\mathrm{VG}$ & $\mathrm{VG}$ & $\mathrm{G}$ & $\mathrm{G}$ \\
$\mathrm{A}_{4}$ & $\mathrm{VP}$ & $\mathrm{MG}$ & $\mathrm{MG}$ & $\mathrm{F}$ & $\mathrm{MP}$ & $\mathrm{MP}$ & $\mathrm{MP}$ & $\mathrm{MG}$ & $\mathrm{MP}$ \\
$\mathrm{A}_{5}$ & $\mathrm{MP}$ & $\mathrm{P}$ & $\mathrm{MP}$ & $\mathrm{F}$ & $\mathrm{F}$ & $\mathrm{F}$ & $\mathrm{MG}$ & $\mathrm{MP}$ & $\mathrm{F}$ \\
$\mathrm{A}_{6}$ & $\mathrm{~F}$ & $\mathrm{G}$ & $\mathrm{MG}$ & $\mathrm{G}$ & $\mathrm{MG}$ & $\mathrm{VG}$ & $\mathrm{G}$ & $\mathrm{VG}$ & $\mathrm{G}$ \\
\hline DM2 & $\mathrm{C}_{1}$ & $\mathrm{C}_{2}$ & $\mathrm{C}_{3}$ & $\mathrm{C}_{4}$ & $\mathrm{C}_{5}$ & $\mathrm{C6}$ & $\mathrm{C}_{7}$ & $\mathrm{C}_{8}$ & $\mathrm{C} 9$ \\
\hline $\mathrm{A} 1$ & $\mathrm{MP}$ & $\mathrm{MG}$ & $\mathrm{F}$ & $\mathrm{F}$ & $\mathrm{MG}$ & $\mathrm{G}$ & $\mathrm{F}$ & $\mathrm{F}$ & $\mathrm{P}$ \\
$\mathrm{A} 2$ & $\mathrm{~F}$ & $\mathrm{G}$ & $\mathrm{F}$ & $\mathrm{P}$ & $\mathrm{F}$ & $\mathrm{MG}$ & $\mathrm{MP}$ & $\mathrm{F}$ & $\mathrm{MP}$ \\
$\mathrm{A} 3$ & $\mathrm{G}$ & $\mathrm{VG}$ & $\mathrm{MG}$ & $\mathrm{G}$ & $\mathrm{MG}$ & $\mathrm{G}$ & $\mathrm{G}$ & $\mathrm{G}$ & $\mathrm{VG}$ \\
$\mathrm{A} 4$ & $\mathrm{P}$ & $\mathrm{MP}$ & $\mathrm{MG}$ & $\mathrm{F}$ & $\mathrm{MP}$ & $\mathrm{MP}$ & $\mathrm{MP}$ & $\mathrm{MG}$ & $\mathrm{F}$ \\
$\mathrm{A} 5$ & $\mathrm{~F}$ & $\mathrm{MP}$ & $\mathrm{F}$ & $\mathrm{P}$ & $\mathrm{F}$ & $\mathrm{F}$ & $\mathrm{MG}$ & $\mathrm{MP}$ & $\mathrm{MG}$ \\
$\mathrm{A} 6$ & $\mathrm{MG}$ & $\mathrm{G}$ & $\mathrm{MG}$ & $\mathrm{MG}$ & $\mathrm{MG}$ & $\mathrm{VG}$ & $\mathrm{VG}$ & $\mathrm{VG}$ & $\mathrm{G}$ \\
\hline DM3 & $\mathrm{C}_{1}$ & $\mathrm{C}_{2}$ & $\mathrm{C}_{3}$ & $\mathrm{C}_{4}$ & $\mathrm{C}_{5}$ & $\mathrm{C} 6$ & $\mathrm{C}_{7}$ & $\mathrm{C}_{8}$ & $\mathrm{C} 9$ \\
\hline $\mathrm{A} 1$ & $\mathrm{MP}$ & $\mathrm{G}$ & $\mathrm{MP}$ & $\mathrm{F}$ & $\mathrm{G}$ & $\mathrm{MG}$ & $\mathrm{F}$ & $\mathrm{MP}$ & $\mathrm{MP}$ \\
$\mathrm{A} 2$ & $\mathrm{MG}$ & $\mathrm{G}$ & $\mathrm{MP}$ & $\mathrm{P}$ & $\mathrm{F}$ & $\mathrm{F}$ & $\mathrm{MP}$ & $\mathrm{MP}$ & $\mathrm{P}$ \\
$\mathrm{A} 3$ & $\mathrm{~F}$ & $\mathrm{MP}$ & $\mathrm{F}$ & $\mathrm{MP}$ & $\mathrm{MP}$ & $\mathrm{G}$ & $\mathrm{G}$ & $\mathrm{P}$ & $\mathrm{MG}$ \\
$\mathrm{A} 4$ & $\mathrm{MP}$ & $\mathrm{F}$ & $\mathrm{MG}$ & $\mathrm{F}$ & $\mathrm{MP}$ & $\mathrm{P}$ & $\mathrm{F}$ & $\mathrm{MG}$ & $\mathrm{F}$ \\
$\mathrm{A} 5$ & $\mathrm{VG}$ & $\mathrm{VG}$ & $\mathrm{MG}$ & $\mathrm{VG}$ & $\mathrm{G}$ & $\mathrm{VG}$ & $\mathrm{G}$ & $\mathrm{MG}$ & $\mathrm{VG}$ \\
$\mathrm{A} 6$ & $\mathrm{MG}$ & $\mathrm{MG}$ & $\mathrm{G}$ & $\mathrm{G}$ & $\mathrm{G}$ & $\mathrm{VG}$ & $\mathrm{VG}$ & $\mathrm{G}$ & $\mathrm{G}$ \\
\hline
\end{tabular}

By defining the membership function, linguistic values are transformed into the corresponding fuzzy numbers, and two intervals are formed. To solve a group decision model, it is calculated the average values for each supplier according to certain criteria. The average values of the alternatives and weights are presented in Tables 7 and 8 .

Table 7. Average values for alternatives at the first interval

\begin{tabular}{c|ccccccccc}
\hline & $\mathrm{C}_{1}$ & $\mathrm{C}_{2}$ & $\mathrm{C}_{3}$ & $\mathrm{C}_{4}$ & $\mathrm{C}_{5}$ & $\mathrm{C}_{6}$ & $\mathrm{C}_{7}$ & $\mathrm{C}_{8}$ & $\mathrm{C}_{9}$ \\
\hline \multirow{2}{*}{$\mathrm{A}_{1}$} & 0.00, & 4.17, & 0.83, & 3.50, & 4.83, & 4.83, & 2.50, & 0.83, & 0.00, \\
& $2.33,3.83$ & $7.00,8.00$ & $3.00,4.50$ & $6.33,7.50$ & $7.67,8.50$ & $7.67,8.50$ & $5.00,6.50$ & $3.67,5.17$ & $1.67,3.17$ \\
$\mathrm{~A}_{2}$ & 3.17, & 3.67, & 1.67, & 1.50, & 3.17, & 3.17, & 0.00, & 1.67, & 0.00, \\
& $5.67,7.00$ & $7.00,7.83$ & $4.33,5.83$ & $3.00,4.33$ & $5.67,7.00$ & $5.67,7.00$ & $2.33,3.83$ & $4.33,5.83$ & $2.33,3.83$ \\
$\mathrm{~A}_{3}$ & 4.50, & 4.67, & 4.17, & 3.67, & 3.00, & 6.50, & 6.50, & 3.67, & 6.17, \\
& $7.67,8.50$ & $7.33,8.00$ & $7.00,8.00$ & $7.00,7.83$ & $5.67,6.83$ & $9.33,9.67$ & $9.33,9.67$ & $6.33,7.17$ & $8.67,9.17$ \\
$\mathrm{~A}_{4}$ & 0.00, & 2.33, & 4.50, & 2.50, & 0.00, & 0.00, & 0.83, & 4.50, & 1.67, \\
& $1.33,2.67$ & $5.00,6.33$ & $7.00,8.00$ & $5.00,6.50$ & $3.00,4.50$ & $2.33,3.83$ & $3.67,5.17$ & $7.00,8.00$ & $4.33,5.83$ \\
$\mathrm{~A} 5$ & 3.67, & 2.83, & 2.33, & 3.67, & 3.50, & 4.50, & 4.83, & 1.50, & 5.17, \\
& $6.00,7.00$ & $4.67,5.67$ & $5.00,6.33$ & $5.33,6.33$ & $6.33,7.50$ & $6.67,7.67$ & $7.67,8.50$ & $4.33,5.67$ & $7.33,8.17$ \\
$\mathrm{~A}_{6}$ & 3.83, & 5.17, & 4.83, & 5.17, & 4.83, & $8.50,10$, & 7.50, & 7.50, & 5.50, \\
& $6.33,7.50$ & $8.33,9.00$ & $7.67,8.50$ & $8.33,9.00$ & $7.67,8.50$ & 10 & $9.67,9.83$ & $9.67,9.83$ & $9.00,9.50$ \\
\hline $\mathrm{w}$ & 0.15 & 0.08 & 0.24 & 0.31 & 0.05 & 0.02 & 0.05 & 0.08 & 0.03 \\
\hline
\end{tabular}


Adis Puška, Safet Kozarević, Željko Stević, Jasmin Stovrag

Table 8. Average values for alternatives at the second interval

\begin{tabular}{c|ccccccccc}
\hline & $\mathrm{C}_{1}$ & $\mathrm{C}_{2}$ & $\mathrm{C}_{3}$ & $\mathrm{C}_{4}$ & $\mathrm{C}_{5}$ & $\mathrm{C}_{6}$ & $\mathrm{C}_{7}$ & $\mathrm{C}_{8}$ & $\mathrm{C}_{9}$ \\
\hline \multirow{2}{*}{$\mathrm{A}_{1}$} & 1.17, & 5.50, & $1.8,3.00$, & 4.83, & 6.17, & $6.17,7.67$, & 3.50, & 2.17, & 0.83, \\
& $2.33,4.83$ & $7.00,9.00$ & 5.50 & $6.33,8.33$ & $7.67,9.67$ & 9.67 & $5.00,7.50$ & $3.67,6.17$ & $1.67,4.17$ \\
& 4.17, & 5.50, & 2.83, & 2.17, & 4.17, & $4.17,5.67$, & 1.17, & 2.83, & 1.17, \\
$\mathrm{~A}_{2}$ & $5.67,8.17$ & $7.00,8.50$ & $4.33,6.83$ & $3.00,5.50$ & $5.67,8.17$ & 8.17 & $2.33,4.83$ & $4.33,6.83$ & $2.33,4.83$ \\
& 6.17, & 6.17, & 5.50, & 5.50, & 4.17, & $8.17,9.33$, & 8.17, & 5.17, & 7.50, \\
$\mathrm{~A}_{3}$ & $7.67,9.17$ & $7.33,8.50$ & $7.00,9.00$ & $7.00,8.50$ & $5.67,8.17$ & 10 & $9.33,10$ & $6.33,7.83$ & $8.67,9.83$ \\
& 0.67, & 3.50, & 5.50, & 3.50, & 1.50, & $1.17,2.33$, & 2.17, & 5.50, & 2.83, \\
$\mathrm{~A}_{4}$ & $1.33,3.50$ & $5.00,7.50$ & $7.00,9.50$ & $5.00,7.50$ & $3.00,5.50$ & 4.83 & $3.67,6.17$ & $7.00,9.50$ & $4.33,6.83$ \\
& 4.83, & 3.83, & 3.50, & 4.50, & 4.83, & $5.50,6.67$, & 6.17, & 2.83, & 6.17, \\
$\mathrm{~A}_{5}$ & $6.00,7.67$ & $4.67,6.33$ & $5.00,7.50$ & $5.33,7.00$ & $6.33,8.33$ & 8.33 & $7.67,9.67$ & $4.33,6.83$ & $7.33,9.00$ \\
& 4.83, & 6.83, & 6.17, & 6.83, & 6.17, & $9.50,10,10$ & 8.83, & 8.83, & 7.50, \\
$\mathrm{~A}_{6}$ & $6.33,8.83$ & $8.33,9.83$ & $7.67,9.67$ & $8.33,9.83$ & $7.67,9.67$ & & $9.67,10$ & $9.67,10$ & $9.00,10$ \\
\hline $\mathrm{w}$ & 0.15 & 0.08 & 0.24 & 0.31 & 0.05 & 0.02 & 0.05 & 0.08 & 0.03 \\
\hline
\end{tabular}

After a decision matrix has been formed for both intervals, data normalization is performed. The next step of the IVFS TOPSIS method is the multiplication of the normalized values with the corresponding weights of the criteria, and forming a weighted decision matrix.

Table 9. A weighted decision matrix for the first interval

\begin{tabular}{c|ccccccccc}
\hline & $\mathrm{C}_{1}$ & $\mathrm{C}_{2}$ & $\mathrm{C}_{3}$ & $\mathrm{C}_{4}$ & $\mathrm{C}_{5}$ & $\mathrm{C}_{6}$ & $\mathrm{C}_{7}$ & $\mathrm{C}_{8}$ & $\mathrm{C}_{9}$ \\
\hline \multirow{2}{*}{$\mathrm{A}_{1}$} & 0.00, & 0.03, & 0.02, & 0.11, & 0.02, & 0.01, & 0.01, & 0.01, & 0.00, \\
& $0.04,0.06$ & $0.05,0.06$ & $0.07,0.11$ & $0.19,0.23$ & $0.04,0.04$ & $0.01,0.02$ & $0.02,0.03$ & $0.03,0.04$ & $0.00,0.01$ \\
$\mathrm{~A}_{2}$ & 0.05, & 0.03, & 0.04, & 0.05, & 0.02, & 0.01, & 0.00, & 0.01, & 0.00, \\
& $0.09,0.11$ & $0.05,0.06$ & $0.11,0.14$ & $0.09,0.13$ & $0.03,0.03$ & $0.01,0.01$ & $0.01,0.02$ & $0.03,0.05$ & $0.01,0.01$ \\
$\mathrm{~A}_{3} 3$ & 0.07, & 0.04, & 0.10, & 0.11, & 0.01, & 0.01, & 0.03, & 0.03, & 0.02, \\
& $0.12,0.13$ & $0.06,0.06$ & $0.17,0.19$ & $0.21,0.24$ & $0.03,0.03$ & $0.02,0.02$ & $0.04,0.05$ & $0.05,0.06$ & $0.02,0.03$ \\
$\mathrm{~A}_{4}$ & 0.00, & 0.02, & 0.11, & 0.08, & 0.00, & 0.00, & 0.00, & 0.04, & 0.00, \\
& $0.02,0.04$ & $0.04,0.05$ & $0.17,0.19$ & $0.15,0.20$ & $0.01,0.02$ & $0.00,0.01$ & $0.02,0.02$ & $0.05,0.06$ & $0.01,0.02$ \\
$\mathrm{~A}_{5}$ & 0.06, & 0.02, & 0.06, & 0.11, & 0.02, & 0.01, & 0.02, & 0.01, & 0.01, \\
& $0.09,0.11$ & $0.04,0.04$ & $0.12,0.15$ & $0.16,0.19$ & $0.03,0.04$ & $0.01,0.01$ & $0.04,0.04$ & $0.03,0.04$ & $0.02,0.02$ \\
$\mathrm{~A}_{6}$ & 0.06, & 0.04, & 0.12, & 0.16, & 0.02, & 0.02, & 0.04, & 0.06, & 0.02, \\
& $0.10,0.11$ & $0.07,0.07$ & $0.19,0.21$ & $0.26,0.28$ & $0.04,0.04$ & $0.02,0.02$ & $0.05,0.05$ & $0.08,0.08$ & $0.03,0.03$ \\
\hline
\end{tabular}

Table 10. A weighted decision matrix for the second interval

\begin{tabular}{c|ccccccccc}
\hline & $\mathrm{C}_{1}$ & $\mathrm{C}_{2}$ & $\mathrm{C}_{3}$ & $\mathrm{C}_{4}$ & $\mathrm{C}_{5}$ & $\mathrm{C}_{6}$ & $\mathrm{C}_{7}$ & $\mathrm{C}_{8}$ & $\mathrm{C}_{9}$ \\
\hline \multirow{2}{*}{$\mathrm{A}_{1}$} & 0.02, & 0.04, & 0.04, & 0.15, & 0.03, & 0.01, & 0.02, & 0.02, & 0.00, \\
& $0.04,0.07$ & $0.05,0.07$ & $0.07,0.13$ & $0.19,0.26$ & $0.04,0.05$ & $0.01,0.02$ & $0.02,0.04$ & $0.03,0.05$ & $0.00,0.01$ \\
$\mathrm{~A}_{2}$ & 0.06, & 0.04, & 0.07, & 0.07, & 0.02, & 0.01, & 0.01, & 0.02, & 0.00, \\
& $0.09,0.12$ & $0.05,0.07$ & $0.11,0.17$ & $0.09,0.17$ & $0.03,0.04$ & $0.01,0.02$ & $0.01,0.02$ & $0.03,0.05$ & $0.01,0.01$ \\
$\mathrm{~A}_{3}$ & 0.09, & 0.05, & 0.13, & 0.17, & 0.02, & 0.02, & 0.04, & 0.04, & 0.02, \\
& $0.12,0.14$ & $0.06,0.07$ & $0.17,0.22$ & $0.21,0.26$ & $0.03,0.04$ & $0.02,0.02$ & $0.04,0.05$ & $0.05,0.06$ & $0.02,0.03$ \\
$\mathrm{~A}_{4}$ & 0.01, & 0.03, & 0.13, & 0.11, & 0.01, & 0.00, & 0.01, & 0.04, & 0.01, \\
& $0.02,0.05$ & $0.04,0.06$ & $0.17,0.23$ & $0.15,0.23$ & $0.01,0.03$ & $0.00,0.01$ & $0.02,0.03$ & $0.05,0.07$ & $0.01,0.02$ \\
$\mathrm{~A}_{5}$ & 0.07, & 0.03, & 0.09, & 0.14, & 0.02, & 0.01, & 0.03, & 0.02, & 0.02, \\
& $0.09,0.12$ & $0.04,0.05$ & $0.12,0.18$ & $0.16,0.21$ & $0.03,0.04$ & $0.01,0.02$ & $0.04,0.05$ & $0.03,0.05$ & $0.02,0.03$ \\
$\mathrm{~A}_{6}$ & 0.07, & 0.05, & 0.15, & 0.21, & 0.03, & 0.02, & 0.04, & 0.07, & 0.02, \\
& $0.10,0.13$ & $0.07,0.08$ & $0.19,0.24$ & $0.26,0.30$ & $0.04,0.05$ & $0.02,0.02$ & $0.05,0.05$ & $0.08,0.08$ & $0.03,0.03$ \\
\hline
\end{tabular}


A New Way of Applying Interval Fuzzy Logic in Group Decision Making for Supplier Selection

Since a weighted matrix of decision-making is formed, it is necessary for each of the criteria to determine a positive and negative ideal point and to determine the relative proximity of the alternatives to the ideal results using formulas 24 and 25 .

Table 11. Results and ranking alternatives

\begin{tabular}{ccccccccc}
\hline & \multicolumn{3}{c}{ First interval } & \multicolumn{3}{c}{ Second interval } & \multirow{2}{*}{$\mathrm{CC}^{*}$} & \multirow{2}{*}{ Rank } \\
& $\mathrm{D}_{\mathrm{i} 1}{ }^{+}$ & $\mathrm{D}_{\mathrm{i} 1}{ }^{-}$ & $\mathrm{CC}_{1}$ & $\mathrm{D}_{\mathrm{i} 2}{ }^{+}$ & $\mathrm{D}_{\mathrm{i} 1}{ }^{-}$ & $\mathrm{CC}_{2}$ & & \\
\hline $\mathrm{A}_{1}$ & 0.328 & 0.163 & 0.332 & 0.335 & 0.168 & 0.334 & 0.333 & 5 \\
$\mathrm{~A}_{2}$ & 0.358 & 0.132 & 0.268 & 0.366 & 0.136 & 0.271 & 0.270 & 6 \\
$\mathrm{~A}_{3}$ & 0.104 & 0.388 & 0.789 & 0.103 & 0.399 & 0.795 & 0.792 & 2 \\
$\mathrm{~A}_{4}$ & 0.304 & 0.187 & 0.381 & 0.312 & 0.194 & 0.383 & 0.382 & 4 \\
$\mathrm{~A}_{5}$ & 0.248 & 0.244 & 0.496 & 0.259 & 0.245 & 0.486 & 0.491 & 3 \\
$\mathrm{~A}_{6}$ & 0.017 & 0.472 & 0.966 & 0.017 & 0.485 & 0.967 & 0.966 & 1 \\
\hline
\end{tabular}

Table 11 gives aggregate results and shows that $A_{6}$ is the best ranked supplier while the worst ranked supplier is $\mathrm{A}_{2}$.

\section{Sensitivity analysis}

When performing the sensitivity analysis, a change in the weights of the criteria is made, and the effect on the result of the analysis is examined. When conducting the sensitivity analysis in this paper, the change in the strength of the criteria was applied so that to all DMs the biggest strength was given to one criterion, while the importance of the other criteria remained unchanged. Using this principle, 9 different calculations were obtained. The weight changes according to each criterion are presented in Table 12. In the first calculation, in all DM, the value of the $\mathrm{C} 1$ criterion was changed in "absolutely strong", while the value of the other criteria remained unchanged. This procedure was applied to all criteria.

Table 12. Criterion weights in sensitivity analysis

\begin{tabular}{l|ccccccccc}
\hline & 1 & 2 & 3 & 4 & 5 & 6 & 7 & 8 & 9 \\
\hline $\mathrm{C}_{1}$ & 0.42 & 0.10 & 0.12 & 0.12 & 0.09 & 0.09 & 0.09 & 0.10 & 0.10 \\
$\mathrm{C}_{2}$ & 0.07 & 0.43 & 0.07 & 0.07 & 0.05 & 0.05 & 0.05 & 0.06 & 0.05 \\
$\mathrm{C}_{3}$ & 0.14 & 0.13 & 0.43 & 0.17 & 0.13 & 0.13 & 0.13 & 0.14 & 0.15 \\
$\mathrm{C}_{4}$ & 0.17 & 0.16 & 0.19 & 0.44 & 0.16 & 0.16 & 0.16 & 0.16 & 0.15 \\
$\mathrm{C}_{5}$ & 0.04 & 0.04 & 0.04 & 0.04 & 0.43 & 0.03 & 0.03 & 0.04 & 0.03 \\
$\mathrm{C}_{6}$ & 0.02 & 0.02 & 0.02 & 0.02 & 0.02 & 0.44 & 0.02 & 0.02 & 0.02 \\
$\mathrm{C}_{7}$ & 0.05 & 0.04 & 0.05 & 0.05 & 0.04 & 0.03 & 0.42 & 0.04 & 0.03 \\
$\mathrm{C}_{8}$ & 0.06 & 0.06 & 0.07 & 0.07 & 0.05 & 0.05 & 0.06 & 0.43 & 0.05 \\
$\mathrm{C}_{9}$ & 0.02 & 0.02 & 0.03 & 0.03 & 0.02 & 0.02 & 0.02 & 0.02 & 0.43 \\
\hline
\end{tabular}

By applying these methods of conducting the sensitivity analysis, results have been obtained that the values of the criteria for which the strength "absolutely strong" were assigned were between 0.42 and 0.44 . In this way, the value of this criterion is absolutely higher than other criteria. By using the weights presented in Table 14, the results of the sensitivity analysis presented in Figure 2 are obtained. 


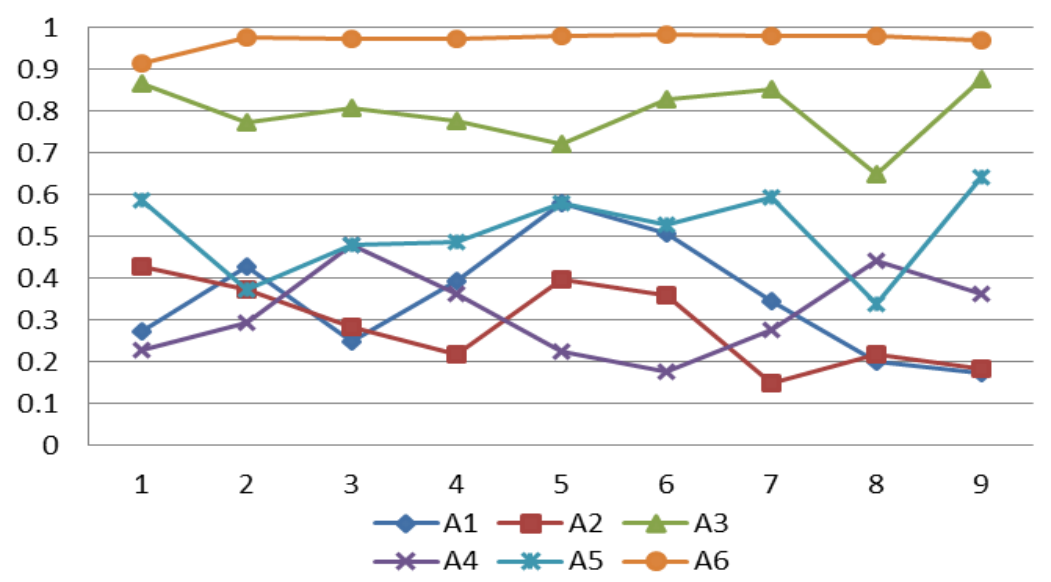

Figure 2. New $\mathrm{CC}^{*}$ values of the alternatives

The obtained results of the sensitivity analysis show that supplier $\mathrm{A}_{6}$ is completely insensitive to the change in the weights of certain criteria and has shown the best results in all 9 calculations. Similar results are shown by the supplier $A_{3}$, who was in second place in all the changes in the criteria. The biggest change in the results of this supplier was when $\mathrm{C}_{8}$ criterion were changed - delivery time. Supplier $\mathrm{A}_{5}$ showed sensitivity to $\mathrm{C}_{2}$ - product certification changes, when it split 4 th place with $A_{2}$ supplier and when $C_{8}$ criterion was changed, when $A_{4}$ supplier was better than him. In changing $C_{9}$ criterion this supplier has achieved the best results. Supplier $A_{1}$ showed the highest sensitivity when changing the criteria $C_{3}, C_{8}$ and $\mathrm{C}_{9}$ when it showed the worst results compared to other suppliers. The best result he was achieved when changing the $\mathrm{C}_{5}$ criterion. $\mathrm{A}_{4}$ supplier showed the highest sensitivity to changes in the $\mathrm{C}_{1}, \mathrm{C}_{5}$ and $\mathrm{C}_{6}$ criteria, where he scored the worst result compared to other suppliers. The best results were achieved by this supplier when changing the criterion $\mathrm{C}_{3}$. Supplier $\mathrm{A}_{2}$ achieved the worst results in changing the $\mathrm{C}_{7}$ criterion and the best results for $\mathrm{C}_{1}$ criterion when this supplier got fourth place in ranking.

\section{Conclusion}

A supplier's selection is a technique for estimating a limited number of suppliers and a selection of suppliers that best meets the decision-making goals. On this basis, the aim of this work is analyzing the potential suppliers and selects the best supplier by using interval fuzzy logic. Many criteria influence this selection which makes the decision making process more difficult. Due to the existence of different types of criteria fuzzy approach simplifies the process of evaluating suppliers using linguistic values. In the paper the IVFS AHP is used to assess the weights of criteria and IVFS TOPSIS method is used to select suppliers. The results showed that supplier $\mathrm{A}_{6}$ showed the best results and the smallest sensitivity to the change in the weights of the criteria. This evaluation of suppliers has proven to be very useful when applying different criteria. In future studies, the above procedure should be 
A New Way of Applying Interval Fuzzy Logic in Group Decision Making for Supplier Selection

applied to other MCDM methods and different ways of determining the weights of the criteria as well as using other criteria.

\section{REFERENCES}

[1]Ashtiani, B., Haghighirad, F., Makui A., Ali Montazer G. (2009), Extension of Fuzzy TOPSIS Method Based on Interval-valued Fuzzy Sets. Applied Soft Computing, 9, 457-461;

[2]Chen, C.T. (2000), Extensions of the TOPSIS for Group Decision-making under Fuzzy Environment. Fuzzy Sets and Systems, 114(1), 1-9;

[3]Chen, S.J., Hwang, C.L. (1992), Fuzzy Multiple Attribute Decision Making.

Springer Verlag, Berlin;

[4]Ghorabaee, M. K., Zavadskas, E. K., Amiri, M., Antucheviciene, J. (2016), A New Method of Assessment Based on Fuzzy Ranking and Aggregated Weights (AFRAW) for MCDM Problems under Type-2 Fuzzy Environment. Economic Computation and Economic Cybernetics Studies and Research, 50(1), 39-69; [5] Gorzalczany, M.B. (1987), A Method of Inference in Approximate Reasoning Based on Interval-Valued Fuzzy Sets. Fuzzy Sets and Systems 21(1), 1-17;

[6]Hwang, C.L., Yoon, K. (1981), Multiple Attributes Decision Making Methods and Applications. Springer, Berlin Heidelberg;

[7]Junior, F.R.L., Osiro, L., Carpinetti, L.C.R. (2014), A Comparison between Fuzzy AHP and Fuzzy TOPSIS Methods to Supplier Selection. Applied Soft Computing, 21, 194-209;

[8]Kabir, G. (2012), Third Party Logistic Service Provider Selection Using Fuzzy AHP and TOPSIS Method. International Journal for Quality Research, 6(1), 71-79;

[9]Kahraman, C., Sari, I.U., Turanoglu, E. (2012), Fuzzy Analytic Hierarchy Process with Type-2 Fuzzy Sets. Proceedings of the 19th International FLINS Conference, 201-206;

[10]Kannan, D., Khodaverdi, R., Olfat, L., Jafarian, A., Diabat, A. (2013), Integrated Fuzzy Multi Criteria Decision Making Method and Multi-Objective Programming Approach for Supplier Selection and Order Allocation in a Green Supply Chain. Journal of Cleaner Production, 47, 355-367;

[11]Lu, J., Zhang, G., Ruan, D. (2007), Multi-Objective Group Decision Making-Methods, Software and Applications with Fuzzy Set Techniques. Imperial College Press, London;

[12]Mousavi, S.M., Vahdani, B., Tavakkoli-Moghaddam, R., Ebrahimnejad S., Amiri, M. (2013), A Multistage Decision Making Process for Multiple Attributes Analysis under an Interval-Valued Fuzzy Environment. International Journal of Advanced Manufacturing Technology, 64(9), 1263-1273; 
Adis Puška, Safet Kozarević, Željko Stević, Jasmin Stovrag

[13]Önüt, S., Soner Kara, S., Isik, E. (2009), Long Term Supplier Selection Using a Combined Fuzzy MCDM Approach: A Case Study for a

Telecommunication Company. Expert Systems with Applications, 36(2), 38873895 ;

[14]Oztaysi, B. (2015), A Group Decision Making Approach Using Interval Type-2 Fuzzy AHP for Enterprise Information Systems Project Selection. Journal of Multiple-Valued Logic and Soft Computing, 24(5-6), 475-500;

[15]Puška, A. (2011), Rangiranje investicionih projekata pomoću modifikovane AHP metode. Tranzicija, 12(28), 125-136;

[16]Saaty, T.L. (1980), The Analytic Hierarchy Process. McGraw Hill, New York;

[17]Sari, I.U., Oztaysi, B., Kahraman, C. (2013), Fuzzy AHP Using Type II Fuzzy Sets: An Application to Warehouse Location Selection. In M. Doumpos and E. Grigoroudis Eds. Multicriteria Decision Aid and Artificial Intelligence: Links, Theory and Applications, Wiley, 258-308;

[18]Stević, Ž., Tanackov, I., Vasiljević, M., Novarlić B., Stojić, G. (2016), An Integrated Fuzzy AHP and Topsis Model for Supplier Evaluation. Serbian Journal of Management, 11(1), 15-27;

[19]Tamošaitienė, J., Zavadskas, E.K., Šileikaitė I., Turskis, Z. (2017), A Novel Hybrid MCDM Approach for Complicated Supply Chain Management Problems in Construction. Procedia Engineering, 172, 1137-1145;

[20]Turskis, Z. Zavadskas, E. K. (2010), A New Fuzzy Additive Ratio Assessment Method (ARAS-F). Case Study: The Analysis of Fuzzy Multiple Criteria in Order to Select the Logistic Centers Location. Transport, 25(4), 423432;

[21]Yazdani, M., Alidoosti, A., Zavadskas, E. K. (2011), Risk Analysis of Critical Infrastructures Using Fuzzy COPRAS. Economic research, 24(4), 27-40; [22]Zadeh, L. A. (1965), Fuzzy sets. Information and Control, 8(3), 338-353; [23]Zeydan, M., Çolpan, C., Çobanoglu, C. (2011), A Combined Methodology for Supplier Selection and Performance Evaluation. Expert Systems with Applications, 38(3), 2741-2751. 